\title{
Bullying at Work and Mental Health: The Moderating Role of Demographic and Occupational Variables
}

\author{
Anna Skuzińska', Mieczysław Plopa², and Wojciech Plopa² \\ 1 Faculty of Administration and Social Sciences, Elbląg University of Humanities and Economy \\ ${ }^{2}$ University of Economics and Human Sciences in Warsaw
}

ABSTRACT

The aim of this study was to investigate the moderating role of individual (gender, age, education), and occupational (employment duration, workplace position, the duration of negative behaviour, and the number of perpetrators) characteristics of victims and perpetrators of negative workplace behaviours in the relationship between workplace bullying and mental health. On the basis of the study on a sample of 904 employees, it was possible to determine the moderating factors. Protective factors contributing to the maintenance of mental health despite experiencing negative workplace behaviours were (a) male sex, (b) a relatively young age, (c) shorter length of job seniority, and (d) postsecondary education or lower. However, it was adverse for the mental health if negative behaviours were exhibited by a superior and when an employee was convinced that there were several perpetrators.

\section{INTRODUCTION}

Since the 1960s, interest in organizational stress and its consequences has been growing rapidly. Among the organizational stressors under examination, one specific group is psycho-sociological stressors (BrukLee \& Spector, 2006; Burke, 1994; Cooper \& Marshall, 1987; Cox et al., 2006; Dormann \& Zapf, 2002; Narayanan et al., 1999) including bullying, which has been discussed in the scientific literature since the 1970s. Workplace bullying is an interpersonal phenomenon consisting of one or more employees, referred to as a perpetrator(s), directing negative behaviours towards another employee, who is usually referred to as the victim (Brodsky, 1976; Dick \& Rayner, 2004; Einarsen et al., 1996; Hoel \& Beale, 2006; Keashly \& Jagatic, 2003; Leymann, 1996a, 1996b; Rayner et al., 2002; Robinson \& Bennett, 1995; Salin, 2003; Vartia-Vaananen, 2003). Important elements of the definition of bullying are the following actions: making a person feel frustrated and socially isolated, tormenting, harassing, insulting, humiliating, abusing (Einarsen et al., 2003), putting a person under pressure (Brodsky, 1976), terrorizing, or otherwise displaying hostile verbal and nonverbal behaviours (Tepper, 2000). The important characteristics of typical bullying behaviours are persistence, that is, the frequency and

Corresponding author: Anna Skuzińska, Faculty of Administration and Social Sciences, Elbląd University of Humanities and Economy, ul. Lotnicza 2, 82-300 Elbląg, Poland. E-mail: a.skuzinska@euh-e.edu.pl 
duration of the behaviours, as well as an imbalance of power between the parties. Leymann (1996b) believed that in order for a perpetrator's behaviour to be classified as bullying, their actions should occur at least once a week for a minimum period of six months.

Workplace bullying leads to consequences for both the company and the employee, namely, their professional performance as well as their physical and mental health. In extreme cases, bullying can cause mental disorders or suicide of the bullied individual (Matthiesen \& Einarsen, 2004; Leymann \& Gustafsson, 1996). Less intense bullying can lead to distress, lowered subjective perception of the quality of one's life, or changes in subjective well-being (Cassidy et al., 2014; Nielsen \& Einarsen, 2012). It has been empirically demonstrated that in comparison to employees who were not bullied, those who experienced bullying report statistically significantly higher scores for anxiety, depression, irritation, psychosomatic symptoms, tiredness, sleep disorders, and professional burnout; they are also characterized by significantly lower self-confidence (Agervold \& Mikkelsen, 2004; Bonde et al. 2016; Brun \& Milczarek, 2007; Butterworth et al., 2016; Einarsen et al., 1998; Mikkelsen \& Einarsen, 2002a; Niedl, 1996; Soares, 2006; Vartia, 2001). Negative experiences in the workplace are negatively correlated with mental health, as measured with the Hopkins Symptom Checklist-25 (HSCL-25, Mikkelsen \& Einarsen, 2001) and the General Health Questionnaire-12 (GHQ-12, Hoel et al., 2004), as well as with satisfaction with life. Longitudinal studies have confirmed the validity of the conclusions about the negative influence of bullying on employees' mental health (i.e., depressive disorders, suicidal ideation, anxiety disorders) and somatic symptoms (i.e., cardiovascular diseases, Kivimaki et al. 2003; Kudielka \& Kern, 2004; Nielsen et al., 2016; Rodriguez-Muñoz et al., 2015; Vartia-Vaananen, 2003).

Research on variables modifying the relationship between negative behaviours at work and mental health has chiefly considered individual (e.g., personality, Nielsen \& Einarsen, 2018; Nielsen et al., 2017; Plopa et al., 2017) as well as social factors (e.g., social support at work, Quine, 2011; Schat \& Kelloway, 2003). Of importance are also (a) demographic and work variables of the victims of negative behaviours and (b) the characteristics of the perpetrators and the negative behaviours themselves. Results on the role of these two groups of variables have been inconclusive thus far.

The first group includes the gender and age of the victims of negative behaviours. Results are contradictory: In Niedl's (1996) study, women experiencing bullying have reported psychosomatic and depressive symptoms more often than did men. Also, Hoel et al. (2004) have shown the relationship between bullying and health variables to be stronger for mental health in women than in men. However, these observations were not confirmed in other studies (Björkqvist et al., 1994; Vartia, 2001). Another demographic variable considered was the age of the victims of negative behaviours. The statistical strength of this relationship increases with age-the older the employee, the stronger this link (Hoel et al., 2004). This effect has not been replicated, however (Vartia, 2001). Being singled out as a target of negative behaviors versus experiencing them as a coworker group has also been examined. Individuals who have not been singled out might learn coping skills to better withstand the long-term effects of these negative behaviors (Rayner et al., 2002). By witnessing how others cope with bullying, individuals can modify their perception of bullying as less threatening and-presumably-experience less intense negative emotions as a result (Rayner, 1997). Variables such as education level or employment duration, on the other hand, have not been usually included in moderator analyses. Few studies have examined the role of workplace position in the relationship between bullying and mental health-a stronger link has been found for regular-level employees than for higher-level executives (Einarsen \& Raknes, 1997). To expand the knowledge on individual moderators in this area, the following hypothesis was formulated:

$\mathrm{H} 1$ : We assumed that the characteristics of individuals experiencing negative behaviours at work (gender, age, employment duration, education, workplace position, being singled out versus targeted as a group, and prior experience of bullying) are moderators of the relationship between negative workplace behaviours and mental health. We expected that negative workplace behaviours will have smaller mental health consequences for young males with shorter employment duration, employees with secondary or higher education, employees that are not singled out for bullying, and employees with no prior bullying experiences.

The second group of variables includes the type of negative behaviours, their duration, and the workplace position of their perpetrators. Numerous studies point to the fact that work-related (e.g., messages and allusions that the employee should quit, intense criticism, unfair or insulting performance evaluations, assigning menial or degrading tasks, limiting the employee's ability to speak in meetings) rather than personal-related (e.g., spreading rumors) negative behaviours are more strongly linked to negative mental health effects. For example, Hoel et al. (2004) have reported that work-related negative behaviors were the most strongly correlated with mental health (measured with the GHQ-12). In a study by Vartia (2001), a strong link between distress (lowered mood, anxiety, exhaustion, insomnia) and both personaland work-related negative behaviours has been observed. However, other research has shown personal-related negative behaviours to be more strongly linked with mental health variables (Einarsen \& Raknes, 1997; Einarsen et al., 1996; Zapf et al., 1996).

The results on bullying duration and mental health show that lower mental health variable scores in people experiencing long-term bullying might be a result of an interaction between the duration and frequency of negative behaviors (Keashly \& Jagatic, 2003; Mikkelsen \& Einarsen, 2002b; Vartia-Vaananen, 2003).

A reliable predictor of bullying effects might be found in perpetrator characteristics, especially their workplace position relative to the recipient (Harvey \& Keashly, 2005). However, there is no consensus on the effects of bullying by a superior: Some research reports that superior bullying has more deleterious mental health consequences than coworker bullying (Beehr et al., 2003; Einarsen, 1999; Einarsen \& Raknes, 1997; Harvey \& Keashly, 2005; Kelloway \& Day, 2005). Keashly and Neuman (2002, qtd in. Harvey \& Keashly, 2005) state that supervisor bullying results chiefly in work-related problems, while coworker 
bullying has negative effects on workplace social relationships. This has been confirmed by Einarsen and Raknes (1997). Related results have also been reported in studies on workplace conflict: Conflict with a supervisor has different results (lower job satisfaction, rotation of positions) than conflict with coworkers (depressive symptoms, lower self-esteem, Bruk-Lee \& Spector, 2006).

The current study seeks to closely analyse the possible role of the factors related to the perpetrators and the characteristics of their negative behaviours in the relationship between bullying and mental health. To this end, the following hypothesis was put forward:

$\mathrm{H} 2$ : We assumed that the characteristics of the negative behaviours and their perpetrators (the number of the perpetrators and the duration of the negative behaviours) are moderators of the relationship between negative behaviors and employees' (i.e., victims') mental health. It was expected that individuals experiencing negative workplace behaviours for a shorter duration and from a single perpetrator will exhibit higher mental health scores.

The results will contribute to the existing knowledge on protective and risk factors for mental health in situations of experiencing intense negative workplace behaviours (bullying).

\section{METHOD}

\section{Materials}

The Polish adaptation of David Goldberg's General Health Questionnaire-28 (GHQ-28) which was developed by Makowska and Merecz (2001; Goldberg \& Williams, 2001), was used to measure mental health. The 28 -item version of the questionnaire was employed, which-apart from the general score-also provides information about the results in four subscales: somatic symptoms (Subscale A), anxiety and insomnia (Subscale B), social dysfunction (Subscale C), and depressive symptoms (Subscale D). The reliability of the Polish adaptation of the GHQ-28, as measured with Cronbach's $\alpha$, ranges from .91 to .93. The reliability of the subscales is as follows: Subscale $\mathrm{A}=.71$ to .93 ; Subscale B $=.70$ to .87 ; Subscale $C=.46$ to .78 ; and Subscale D $=.70$ to .87 (Makowska \& Merecz, 2001). The GHQ-28 has been used in previous studies on the consequences of bullying at work (Hansen et al., 2006; Hoel et al., 2004; Leymann \& Gustafsson, 1996; Mahyew et al., 2004; Vartia-Vaananen, 2003; Warszewska-Makuch, 2008). Another tool used was the Satisfaction with Life Scale (SWLS) by Diener et al. (1985); the Polish version, which was developed by Juczyński (2001), was used in this study. Satisfaction with life, as measured with the SWLS, encompasses the cognitive aspect of subjective well-being and correlates negatively with, among others, depression $(r=-.72)$ and suicidal thoughts $(r$ $=-.44$; Pavot \& Diener, 2008). The Polish normalization of the scale was performed on a sample of 555 people aged 20-55 years, and the scale is characterized by good psychometric values (the reliability of the whole scale, as measured with Cronbach's $\alpha$, was .86 in the Polish research by Juczyński (2001).

Evaluation of negative behaviours was performed with the Negative Acts Questionnaire (NAQ, Einarsen \& Raknes, 1997), which was adapt- ed to Polish by Warszewska-Makuch (2007). For the reliability of the Polish adaptation of the NAQ, Cronbach's a was .94. Subscale reliability was .92 for the subscale of personal derogation (NAQ_Pers) and .90 for the subscale of work-related bullying (NAQ_Work). The NAQ allows for determining the intensity of the negative behaviours that one has experienced and to evaluate self-labelling as a victim of bullying.

\section{Procedure and Participants}

The questionnaire-based survey was conducted in the territory of a city in northern Poland with a population of 130000 people (the sample was almost full after the randomized selection of institutions). Participation in the study was voluntary and anonymous. Administrative staff, policemen, and hospital staff (nurses) participated in the study. In total, 1517 questionnaire sets were distributed, and 904 were returned (response rate of 59.6\%). Each participant received the questionnaires in the following order: the SWLS, the GHQ-28, and the NAQ, along with additional questions about the characteristics of the experienced negative behaviours and their perpetrator. At the end, several sociodemographic questions were included. At the beginning of each set, brief information explaining the purpose of the study was given. The participants returned the completed questionnaires to the researcher in sealed, unmarked envelopes. Among the participants in the study, there were 574 administrative staff members (working in local and state authorities' offices), 86 policemen, and 244 nurses. A total of $82.55 \%$ of the sample was comprised of women. The average age of the respondents was 38.6 years $(S D=9.7)$, and the youngest participant was 21 years old, while the oldest was 67 . More than half of the respondents had a higher education (53\%). Managerial positions were occupied by $12.6 \%$ of the respondents. The average length of job seniority was 17.08 years $(S D=10.43)$. The average length of seniority at the respondents' currently occupied position was slightly over 11 years $(S D=8.5)$. The largest proportion of the respondents worked in companies employing between 50 and 249 people (45.5\%).

\section{Statistical Analysis}

Before carrying out calculations involving the variable of satisfaction with life, it was necessary to recode the results of the SWLS so that the meaning of high and low scores was uniform for all the variables of mental health under examination. After the results of the SWLS were recoded, higher scores attested to poorer mental health while lower scores attested to better mental health for all the dependent variables under analysis. Nonparametric tests were used in the statistical analysis (i.e., for the comparison of averages). Verification of the moderating role of the contextual variables was performed with regression analysis using the SPSS 13 software. The variables included in the regression equation were first standardized; then, an interaction element was made by multiplying the moderator by the independent variable. This element was included in the regression analysis. Interpretation of the significant interaction effects for continuous variables (i.e., age, job seniority) was performed on the basis of the values of the $\beta$ coefficient on various levels of the dependent variable and the moderator $(z=-1$; $z=1$ ) based on the following regression equation: $Y=\beta_{1} \times X+\beta_{2} \times$ 
$M+\beta_{3} \times X M$ (cf. a graphic presentation of interaction in Cranford, 2004; Łuszczyńska \& Cieślak, 2005; Schat \& Kelloway, 2003; Whisman \& McClelland, 2005).

\section{RESULTS}

\section{Descriptive Statistics and Correlations}

The descriptive statistics and correlations among the analysed variables are provided in Table 1.

\section{BULLYING AND NEGATIVE BEHAVIORS}

Bullying frequency (Leymann's criterion) was 20.5\% (185 people). On average, the respondents experienced greater work-related than personal-related negative behaviors, $W(1, N=904)=0.118$; $p<.001$; $\chi^{2}=106.90 d f=1, p<.001$. No statistically significant link between the respondents' age or employment duration and negative behaviors was found, which might suggest that each employee, regardless of their age and workplace experience, can experience negative behaviors. Men experienced significantly greater intensity of work-related negative behaviours $\left(M_{\mathrm{rang}}=517.35\right)$ than did women $\left(M_{\mathrm{rang}}=438.76\right), U=48687$; $p<.001$. Statistically significant differences in work-related negative behaviors, $U=88192$; $p<.01$, were found for employees with secondary education or lower $\left(M_{\text {rang }}=420.49\right)$ and higher education $\left(M_{\text {rang }}=\right.$ 477). Employees with higher education experienced a greater intensity of work-related negative behaviors.

\section{MENTAL HEALTH VARIABLES}

It was found that men exhibited significantly lower somatic symptoms $(U=49013.5 ; p<.01)$, anxiety and insomnia $(U=49753.5 ; p<.01)$, as well as depressive symptoms $(U=52505 ; p<.05)$ than did women, despite the fact that they experienced greater work-related negative behaviors. Regular employees and executives differed only with respect to life satisfaction, $U=35464.5$, with this difference reaching the level of a statistical tendency, $p=.087$ : executives reported slightly higher life satisfaction than regular-level employees.

\section{Verifying the Moderating Role of Personal Characteristics}

The moderating role of personal characteristics of employees experiencing negative workplace behaviours was analysed via regression analysis. The first tested variable was employee gender. A significant interaction for social dysfunction and somatic symptoms was found, alongside a weaker interaction with depressive symptoms. The effect of negative behaviours, both work- and personal-related, on social dysfunction was stronger for women (NAQ_Pers: $\beta=.177 ; p<.001$; NAQ_Work: $\beta=.175 ; p<.001)$ than for men - where it was not statistically significant (NAQ_Pers: $\beta=-.051 ; p=.231$, NAQ_Work: $\beta$ $=.022 ; p=.327)$. A similar relationship was found for somatic symptoms: the influence of work-related negative behaviours was stronger for women $(\beta=.180 ; p<.001)$ than for men $(\beta=.071 ; p=0.185)$. Women and men also differed with respect to the effect of personalrelated negative behaviours on depressive symptoms $(p=.079)$ : Even though this relationship was positive and significant in both groups, it was slightly stronger for women $(\beta=.230 ; p<.001)$ than for men $(\beta$ $=.175 ; p<.05)$.

The respondents' age moderated the relationship between negative behaviours (NAQ_Pers; NAQ_Work) and life satisfaction, depressive symptoms, and social dysfunction (NAQ_Work only). The greater the intensity of negative behaviours and the older the employee, the lower their life satisfaction (see Figure 1; results of the SWLS were recoded, so that the meaning of high and low scores was uniform for all the variables of mental health under examination), NAQ_Pers: $\Delta R^{2}=$ $.004 ; p=.069$; NAQ_Work $=\Delta R^{2}=.008 ; p<.01$, and the stronger the depressive symptoms (see Figure 2), NAQ_Pers: $\Delta R^{2}=.005 ; p<.05$; NAQ_Work: $\Delta R^{2}=.007 ; p<.05$.

Moreover, the more intense the work-related negative behaviors and the older the employee, the stronger the social dysfunction, $\Delta \mathrm{R} 2$ $=.003 ; \mathrm{p}=.081$ (see Figure 3$)$.

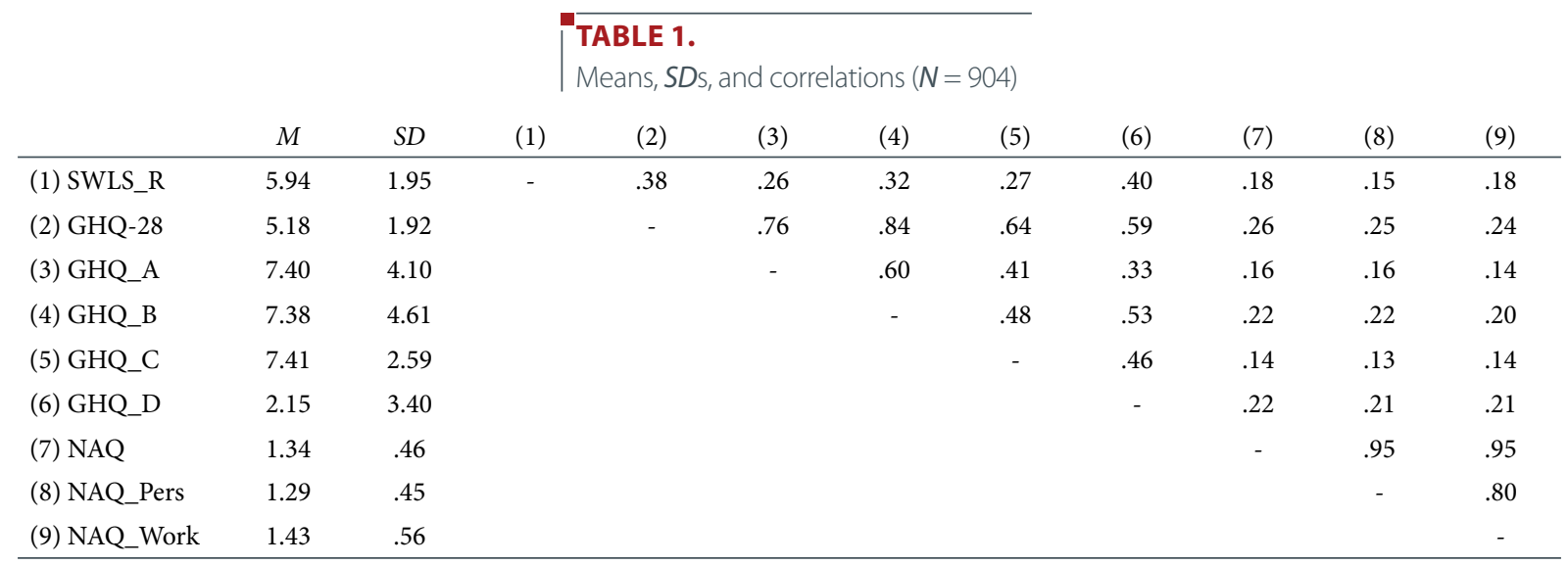

Note. All the correlations are significant at the level of $p<.001$; SWLS_R = Satisfaction with Life Scale total score; GHQ-28=General Health Questionnaire-28 total score; GHQ_A = somatic symptoms; GHQ_B = anxiety and insomnia; GHQ_C = social dysfunction; GHQ_D = depressive symptoms; NAQ = Negative Acts Questionnaire; NAQ_Pers = personal derogation; NAQ_Work = work-related bullying. 


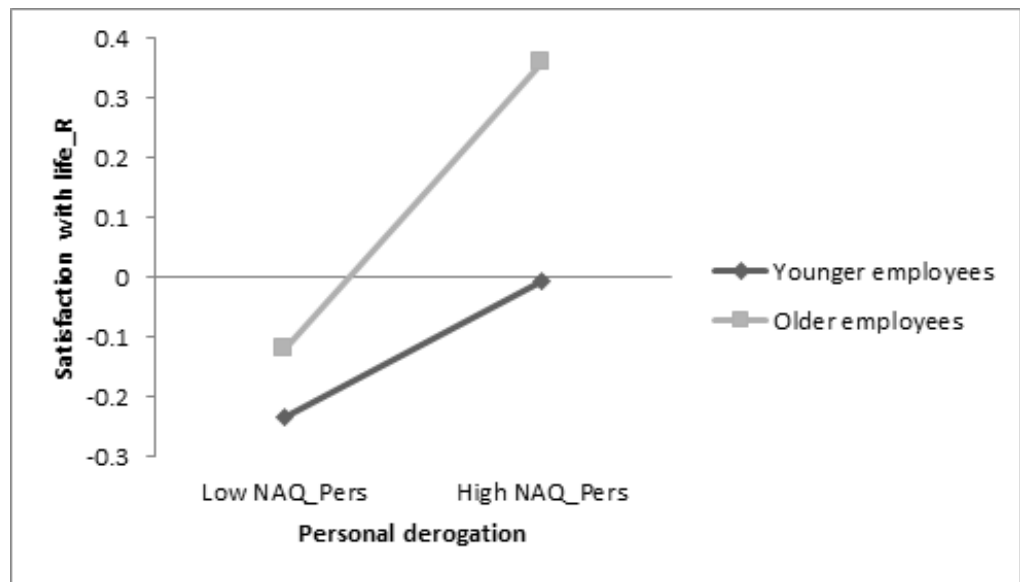

FIGURE 1.

Interaction between the respondents' age and the intensity of personal derogation; the dependent variable was satisfaction with life.

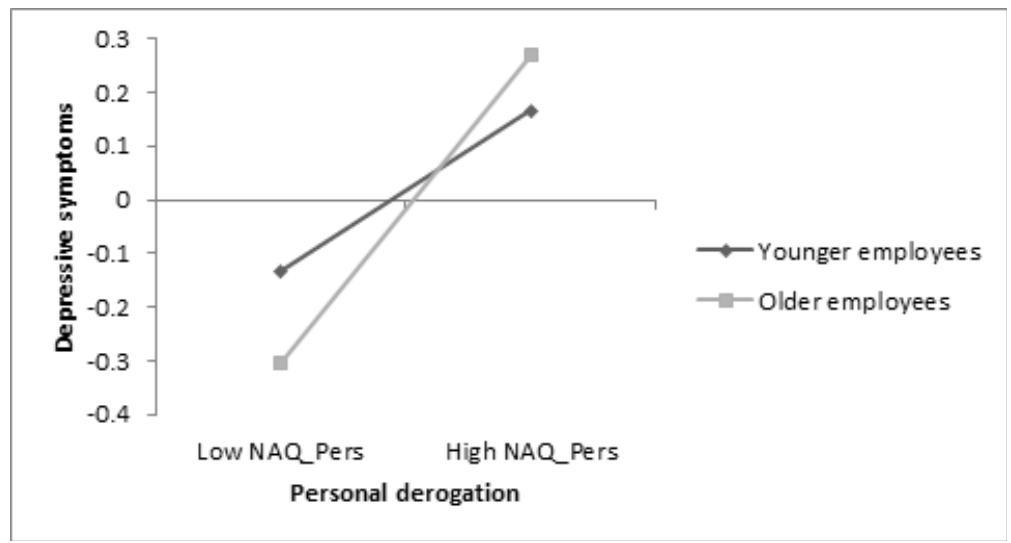

FIGURE 2.

Interaction between the respondents' age and the intensity of personal derogation; the dependent variable was depressive symptoms.

Duration of employment was also revealed to be a significant moderator of the relationship between negative workplace behaviours and mental health, NAQ_Work and SWLS_R: $\Delta R^{2}=.008$; $p<$ .01 ; NAQ_Work and GHQ_D: $\Delta R^{2}=.006 ; p<.05$; NAQ_Pers and SWLS_R: $\Delta R^{2}=.004 ; p=.060$; NAQ_Pers and GHQ_D: $\Delta R^{2}=.003$; $p=.072$. With high intensity of negative behaviors, employees with longer employment duration exhibited stronger depressive symptoms and lesser life satisfaction than did employees with shorter employment duration. A similar relationship has been found for the moderator of employee age: age was strongly correlated with employment duration, $r=.962, p<.001$.

Education also played a moderating role between negative behaviors and mental health. Intense work-related negative behaviors increased anxiety and insomnia for employees with higher education to a significantly greater extent $(\beta=.276 ; p<.001)$ than they did for employees with secondary or lower education $(\beta=.137 ; p<.01)$. It was also found that, for employees with higher education, the effect of work-related negative behaviors for all mental health measures in the current study was characterized by high statistical significance ( $p$ $<.001$ ); for employees with secondary or lower education, significance varied from $p<.05$ to $p<.001$.

No moderating role of workplace position has been found. The influence of negative behaviors on mental health variables among regular-level employees was characterized by greater statistical significance $(p<.001)$ than among executives, where significance did not pass $p<.01$, often (NAQ_Pers and SWLS_R, GHQ_A, GHQ_C, NAQ_ Work, and GHQ_A) not reaching significant levels.

Finally, there were no statistically significant differences in terms of mental health variables when the victim experienced negative behaviours alone or in a group of coworkers. However, people who had experienced negative behaviours in previous workplaces were characterized by more severe somatic symptoms $\left(M_{\text {rang }}=233.97\right)$ 


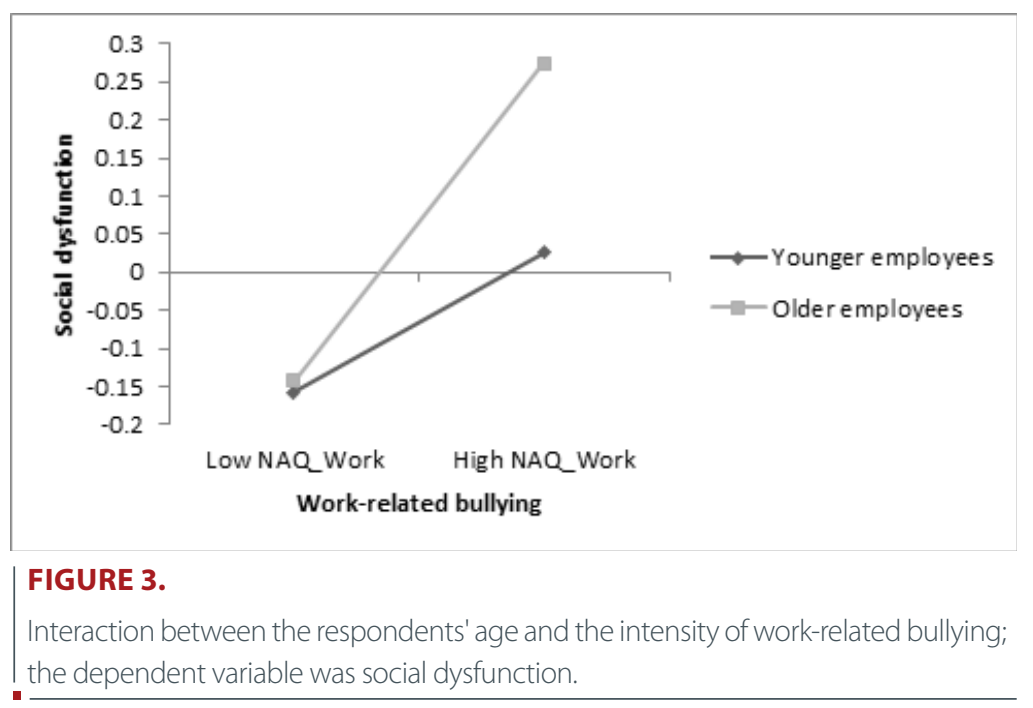

than people who had not previously experienced negative behaviours $\left(M_{\text {rang }}=264.17, \chi^{2}=4.078, d f=1 ; p<.05\right)$. It is possible that somatic symptoms were the consequence of negative behaviours experienced in previous workplaces, which are stretched over a long period of time. However, in this case, it cannot be determined unequivocally without knowledge about the intensity of negative behaviours that an employee experienced in the previous workplace.

\section{Verifying the Moderating Role of Perpetrator and Negative Behavior Characteristics}

The next step was the verification of the moderating role of the characteristics of the perpetrator and their behaviours. Negative behaviour duration and the number of its victims, as indicated by the respondents, were analyzed.

The duration of negative behaviours was revealed to be a moderator only in the group of people experiencing negative behaviours for longer than five years and was absent in people who had experienced negative behaviours for less than five years. In the first group, the influence of negative behaviours on somatic and depressive symptoms was statistically significant at $p<.01$. In this group, the interaction between the duration of negative behaviours and the NAQ scores accounted for between 1\% (NAQ_Work) and 1.3\% (NAQ_Pers) of the variance in somatic symptoms and between 1.6\% (NAQ_Pers) and $1.8 \%$ (NAQ_Work) of the variance in depressive symptoms. Although no significant interaction effect emerged for the variable of the number of perpetrators, a simple effect of the number of perpetrators was observed. People experiencing negative behaviours of several perpetrators were characterized by more intense somatic symptoms $\left(M_{\text {rang }}=238.90\right)$ in comparison to people who indicated that there was only one perpetrator $\left(n=212 ; M_{\text {rang }}=215.51\right), \chi^{2}=3.604, d f=1, p=$ .058). However, it has to be noted that the intensity of the negative behaviours experienced by both groups was comparable $(p=.57)$. The observed simple effect of the number of perpetrators was likely not caused by the presumably greater intensity of negative behaviors carried out by perpetrators in a group

\section{DISCUSSION}

The main objective of the current study was to determine which factors, and under what circumstances, facilitate the preservation of good mental health despite experiencing negative behaviours at work. This objective was accomplished by means of (a) the verification of the moderating role of demographic variables of employees experiencing negative behaviours and (b) the verification of the moderating role of the variables related to the perpetrator and the characteristics of their negative behaviours.

The analysis of the moderators revealed an array of significant interactions. It was determined that $(\mathrm{H} 1)$ the sex, age, education, job seniority of the recipient (victim) of negative behaviours and (H2) duration of the negative behaviours played a moderating role. The existence of simple effects was also discovered, namely, the simple effects of the perpetrator's job position and sex, the number of perpetrators, and experiences of negative behaviours in previous workplaces.

The influence of negative behaviours on somatic symptoms (NAQ_ Work), social dysfunction (NAQ_Pers, NAQ_Work), and depressive symptoms (NAQ_Pers) was stronger in women than in men. This result differs from that observed by Hoel et al. (2004), however, they are consistent with the findings of Niedl (1996). Men, in turn, were characterized by better mental health than women with regard to variables such as anxiety and insomnia as well as depressive and somatic symptoms. The better mental health of men despite the higher intensity of negative behaviours may attest to the existence of different or stronger protective factors in this group. A possible explanation for the obtained results may be connected with the dissimilar strategies of coping with interpersonal stressors adopted by men and women, which were not taken into account in this study; that is, men might avoid these types of stressors more often than women do because they most likely see them as more uncontrollable than do women (Tamres et al., 2002). Perhaps this is why the relationship between negative behaviours and mental health was not statistically significant in the male sample-it is possible that it was not linear owing to the defensive mechanisms used by men (e.g., avoidance, as mentioned above). Regarding women, the correla- 
tion between negative behaviours and mental health is most likely less affected by defensive mechanisms.

Other significant moderators were age and job seniority. Employees who were older and had worked for longer did not cope with experiencing negative behaviours at work as well as younger people did. A similar result for the variable of age was obtained in the study by Hoel et al. (2004). Older employees who had worked for longer may expect respect and credit from coworkers and superiors for their many years of contribution to work; thus, a lack of such recognition, which is contrary to their expectations, may cause distress and lower their subjective well-being. Experiencing bullying at work disrupts cognitive patterns with regard to own self as a competent person and the world as a safe place. Research conducted by Mikkelsen and Einarsen (2002), referring to Janoff-Bulmann's cognitive theory of trauma, demonstrated that bullied people were characterized by a negative conviction about other people's goodwill or that the world is generally good; they also expressed a more negative conviction about themselves (i.e., their self-esteem was low) in comparison to people who had not been bullied. Perhaps older employees who have worked for a longer period of time share a conviction that they deserve respect due to their age and professional experience; this conviction may be stronger than for young people. The inconsistency between individuals' cognitive patterns and reality may lower their subjective well-being. Another possible explanation is concerned with the perception of intentionality of behaviours (Harvey \& Keashly, 2005; Keashly \& Jagatic, 2003). The wider life and professional experience of older employees and their deeper acquaintance with the perpetrator (involving knowledge about their behaviours and motivation) possibly contributes to the fact that these people are more likely than younger employees to interpret the perpetrator's behaviours as intentional, which causes them to be more susceptible to worsening subjective well-being as a consequence of experiencing this type of behaviour. Dick and Rayner (2004) stress the necessity of examining bullying in the context of the relationship between the perpetrator and the victim as it developed over time. The assignment of the quality of intentional infliction of harm to the perpetrators' behaviours has not been thoroughly studied (as the perception of the perpetrator's intentions is rarely taken into consideration in research on bullying), while Keashly and Jagatic (2003) claim that whether intention is assigned or not is significantly contingent upon the context of behaviours (including the duration of negative behaviours and the relationship between the perpetrator and the victim). Another possible explanation for the fact that the influence of negative behaviours on mental health is stronger in the case of older employees is related to professional identity, as identification with one's professional role strengthens with age. Negative behaviours entail a threat of losing one's job, and such a threat may cause greater anxiety in people who strongly identify with their profession (Kalbarczyk, 1999).

Another variable modifying the relationship between negative behaviours and mental health is education: higher mental costs (in the form of greater anxiety and insomnia) of experiencing work-related bullying are accrued by people with higher education rather than people with secondary education or lower. People with higher education may be perceived by the superiors as rivals; high professional qualifications of subordinates are seen as a threat to their own occupational position. In this situation, managers may exhibit more intense negative behaviours oriented towards the work and professional development of their subordinates with higher education rather than that of their subordinates with no such education. Another explanation of this result might be sought within the framework of the personal employment identity model (Peregoy \& Schliebner, 1990): For people who strongly identify with their profession, losing a job (or the threat thereof) may entail the loss (or the threat thereof) of their professional identity. People whose profession requires going through many years of education and constant additional trainings (e.g., by taking postgraduate courses) or is connected with certain distinguishing features (e.g., a uniform, an oath, a necessity to have an internship or take a probationary period) are more involved (including affectively) in their job role; hence, their anxiety and insomnia may be stronger if they experience behaviours that negatively influence their duties (Kalbarczyk, 1999; Karney, 1998; Peregoy \& Schliebner, 1990). Furthermore, people who have higher education attach much greater importance to independent and creative work, which gives them the opportunity to undertake initiatives (Lewandowska \& Wenzel, 2004); thus, work-related bullying (e.g., excessive control of their work or reduced responsibility for important tasks) hampers or precludes the achievement of their goals, which may translate into greater anxiety and insomnia.

Experiencing negative behaviours in previous workplaces (leading to greater intensification of somatic symptoms) and experiencing this type of behaviour over a long period of time are also adverse for mental health. Experiencing negative behaviours for a long time may not only lead to long-term consequences (such as somatic symptoms) but can also be examined in the context of repeated mental injuries. That is, each new incident at work causes an individual to be more susceptible to the emergence of distress (Herman, 1999).

When there were several perpetrators, employees' mental health was lower than when there was only one perpetrator (which was the main effect of the number of perpetrators). In other words, the behaviour of a group (i.e., the power of the influence of a group of perpetrators over an employee) caused a stronger effect (in the form of worsening mental health) than did the behaviour of a single perpetrator, but this effect was not caused by an increased intensity of behaviours (or exerted influence). Rather, it was most likely an effect caused simply by the presence of other perpetrators. This result may be interpreted in the context of research on social influence (Grzelak \& Nowak, 2000; Kenrick et al., 2006). The absence of an increase in the intensity of negative behaviours along with the number of perpetrators may be explained by referring to the phenomenon of normative conformity: Other people's fear of rejection and a desire to gain the perpetrator's acceptance cause them to join the perpetrator. However, these people do not get involved in negative behaviours but rather only serve as the "background" or "audience" watching the perpetrators' behaviours. Rayner et al. (2002) claim that witnesses of bullying who do not react to negative behaviours occurring in their presence may be perceived by the victim as other bullies. The poorer mental health of 
people who indicate several perpetrators probably results from the perceived presence of numerous perpetrators rather than from their actual behaviours. It is possible that when an employee sees several perpetrators in their environment, they will also be more convinced that the possibility of finding help in this environment is low (Pospiszyl, 2003). The perception of the availability of less abundant social resources at work, a hypothetically stronger sense of social isolation and failures in professional relations with many people may contribute to the worsening social condition of people experiencing negative behaviours from the hands of several perpetrators.

Moreover, a main effect of job position was noted; the functioning of people who named their superior as the perpetrator was significantly more disordered than that of people who named a coworker as the perpetrator. In line with the relevant literature (Einarsen, 1999; Harvey \& Keashly, 2005), negative behaviours exhibited by a superior influence, first and foremost, a subordinate's professional development. Although this study does not take into account the variables related to career development, poorer coping with everyday duties may indirectly attest to an individual's poorer professional functioning.

Contrary to expectations and the information available in the relevant literature (Rayner et al., 2002), the main effect of the number of recipients of negative behaviours was not confirmed. It was expected that people who had been experiencing negative behaviours in a group of coworkers would be characterized by better mental health than people who had experienced negative behaviours alone. When several people suffer from negative behaviours, they can develop ways to cope with the consequences of the behaviours of the perpetrator(s). It is possible that people experiencing negative behaviours in a group have worked out common strategies of coping with the consequences of negative behaviours, but perhaps these strategies were not more effective than those used by people experiencing negative behaviours on their own. However, the collected data do not allow for verifying this possibility.

\section{CONCLUSIONS}

On the basis of the study and the statistical analyses that were conducted, it was possible to determine the circumstances contributing both to maintaining relatively good as well as lowered mental health as a result of negative workplace behaviours. Protective factors contributing to the maintenance of mental health despite experiencing negative workplace behaviours were: male sex, a relatively young age, shorter length of job seniority, and postsecondary education or lower. The probability of preserving mental health was also higher when the perpetrator was not a superior but rather a coworker. It is also likely that people who are convinced that the perpetrator acts alone and not in a group will have better mental health. Experiencing negative behaviours for the shortest possible length of time also contributes to better mental health. If employees meet at least one of the above conditions, the probability that they will maintain relatively good mental health when experiencing intense negative workplace behaviours increases.

The risk factors causing employees to be more susceptible to worsening mental health when experiencing intense negative workplace behav- iours were: female sex, a relatively older age, longer length of job seniority, and higher education. It is also adverse for the mental health of an individual if negative behaviours are exhibited by a superior and when an employee reports that there are several perpetrators. Experiencing negative workplace behaviours over a period of many years is also unfavourable for mental health. If an employee meets at least one of the criteria above, the probability of having lowered subjective well-being and suffering from greater distress in the face of negative workplace behaviours increases. Therefore, it seems that the prevention of mental disorders at work and help for people experiencing intense negative behaviours at work should, first and foremost, be oriented towards this group of employees.

\section{ACKNOWLEDGEMENTS}

The authors declare that there is no conflict of interest regarding the publication of this article

\section{REFERENCES}

Agervold, M., \& Mikkelsen, E. G. (2004). Relationship between bullying, psychosocial work environment and individual stress reactions. Work \& Stress, 18, 336-351. doi: 10.1080/02678370412331319794 الفيلس

Beehr, T. A., Farmer, S. J., Glazer, S., Gudanowski, D. M., \& Nair, V. N. (2003). The enigma of social support and occupational stress: Source of congruence and gender role effects. Journal of Occupational Health Psychology, 8, 220-231. doi: 10.1037/1076-8998.8.3.220 سلسلسلس

Björkqvist, K., Österman, K., \& Hjelt-Bäck, M. (1994). Aggression among university employees. Aggressive Behavior, 20, 173-184. doi: 10.1002/1098-2337(1994)20:3<173::AIDAB2480200304>3.0.CO;2-D سلس

Bonde, J. P, Gullander, M., Hansen, A. M., Grynderup, M., Persson, R., Hogh, A., . . \& \& Kolstad, H. A., (2016). Health correlates of workplace bullying: A 3-wave prospective follow-up study. Scandinavian Journal of Work, Environment \& Health, 42, 17-25. doi: 10.5271/sjweh.3539 سلس

Brodsky, C.M. (1976). The harassed worker. Lexington Books, D.C. Heath and Company.

Bruk-Lee, V., \& Spector, P.E. (2006). The social stressors-ocunterproductive work behaviors link: Are conflict with supervisors and coworkers the same? Journal of Occupational Health

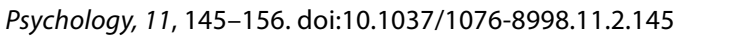

Brun, E., \& Milczarek, M. (2007). Expert forecast on emerging psychosocial risks related to occupational safety and health. Retrieved from www.osha.europa.eu/en/publications/reports/7807118

Burke, R. J. (1994). Sources of managerial and professional stress in large organizations. In C. L. Cooper \& R. Payne (Eds.). Causes, coping and consequences of stress at work (pp. 77-114). John Wiley \& Sons.

Butterworth, P., Leach, L. S., \& Kiely, K. M. (2016). Why it's important for it to stop: Examining the mental health correlates 
of bullying and ill-treatment at work in a cohort study. The Australian And New Zealand Journal of Psychiatry, 50, 10851095. doi: $10.1177 / 0004867415622267$ (السلسلس

Cassidy, T., McLaughlin, M., \& McDowell, E. (2014). Bullying and health at work: The mediating roles of psychological capital and social support. Work \& Stress, 28, 255-269. doi: 10.1080/02678373.2014.927020 1لس

Cooper, C. L., \& Marshall, J. (1987). Sources of stress in managerial and mental work], In C. L. Cooper \& R. Payne (Eds.). Stress at work (pp. 123-163). Państwowe Wydawnictwo Naukowe.

Cox, T., Griffiths, A., \& Rial-Gonzales, E. (2006). Research on stress related to work. Retrieved from https://osha.europa.eu/pl/ publications/factsheet-8-stress-work-summary-agency-report

Cranford, J. A. (2004). Stress-buffering or stress-exacerbation? Social support and social undermining as moderator of the relationship between perceived stress and depressive symptoms among married people. Personal Relationships, 11, 23-40. doi: 10.1111/j.1475-6811.2004.00069.x الس السلسلي

Dick, G., \& Rayner, C. (2004). Exploring the workplace bullying construct: An evidence-based approach. University of Kent, Working Paper Series. No. 75, Retrieved from www.kent.ac.uk/ $\mathrm{KBS} /$ research-information/working-papers/Dick-and-RaynerNo-75.pdf

Diener, E., Emmons, R. A., Larsen, R. J., \& Griffin, S. (1985). The Satisfaction With Life Scale. Journal of Personality Assessment,

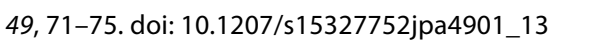

Dormann, C., \& Zapf, D. (2002). Social stressors at work, irritation, and depressive symptoms: Accounting for unmeasured third variables in a multi-wave study. Journal of Occupational and Organizational Psychology, 75, 33-58. doi: 10.1348/096317902167630 الس السلسل

Einarsen, S. (1999). The nature and causes of bullying at work. International Journal of Manpower, 20, 16-27. doi: 10.1108/014377299102685 سلس

Einarsen, S., Hoel, H., Zapf, D., \& Cooper, C. L. (2003). The concept of bullying at work. The European tradition. In: S. Einarsen, $\mathrm{H}$. Hoel, D. Zapf, \& C. L. Cooper (Eds.). Bullying and emotional abuse in the workplace (pp. 3-30). London, England: Taylor \& Francis.

Einarsen, S., Matthiesen, S., \& Skogstad, A. (1998). Bullying, burnout and well-being among assistant nurses. Journal of Occupational Health and Safety, 14, 563-568.

Einarsen, S., \& Raknes, B. I. (1997). Harassment in the workplace and the victimization of men. Violence and Victims, 12, 247236. doi: 10.1891/0886-6708.12.3.247 سلس سلس

Einarsen, S., Raknes, B. I., Matthiesen, S. B., \& Hellesøy, O. H. (1996). Helsemessige aspekter ved mobbing $\mathrm{i}$ arbeidslivet [Health aspects of bullying at work]. Nordisk Psykologi, 48, 116-137. doi: 10.1080/00291463.1996.11863874 1لس

Goldberg, D., \& Williams, P. (2001). Podręcznik dla użytkowników Kwestionariusza Ogólnego Stanu Zdrowia [Manual for the users of the General Health Questionnaire]. Instytut Medycyny Pracy im. prof. J. Nofera.
Grzelak, J. Ł., \& Nowak, A. (2000). Wpływ społeczny [Social influence]. In J. Strelau (Ed.). Psychologia [Psychology] (Vol 3, pp. 187-204). Gdańskie Wydawnictwo Psychologiczne.

Hansen, A. M., Hogh, A., Persson, R., Karlson, B., Garde, A. H., \& Ørbæk, P. (2006). Bullying at work, health outcomes, and physiological stress response. Journal of Psychosomatic Research, 60 ,

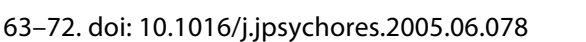

Harvey, S., \& Keashly, L. (2005). Emotional abuse: How the concept sheds light on the understanding of psychological harassment (in Quebec). Pistes, 7. Retrieved from http://www.pistes.uqam. $\mathrm{ca} / \mathrm{v} 7 \mathrm{n3} / \mathrm{pdf} / \mathrm{v} 7 \mathrm{n3a15en.pdf}$

Herman, J. L. (1999). Trauma and recovery. Hachette.

Hoel, H. \& Beale, D. (2006). Workplace bullying, psychological perspectives and industrial relations: Towards a contextualized and interdisciplinary approach. British Journal of Industrial Relations, 44, 239-262. doi: 10.1111/j.1467-8543.2006.00496.x الس السلسل

Hoel, H., Faragher, B., \& Cooper, C. L. (2004). Bullying is detrimental to health, but all bullying behaviour are not necessarily equally damaging. British Journal of Guidance \& Counselling, 32, 367-387. doi: 10.1080/03069880410001723594 الس السلسل

Juczyński, Z. (2001). Narzędzia pomiaru w promocji i psychologii zdrowia [Measurement tools in health promotion and psychology]. Pracownia Testów Psychologicznych Polskiego Towarzystwa Psychologicznego.

Kalbarczyk, A. (1999). Psychologiczne konsekwencje utraty pracy i bezrobocia [Psychological consequences of losing work and unemployment]. In: G. Kranas (Ed.), Organizacja, praca, bezrobocie [Organization, work, and unemployment] (pp. 7-44). Wydawnictwa Uniwersytetu Warszawskiego.

Karney, J. E. (1998). Człowiek i praca [Humans and Work]. Międzynarodowa Szkoła Menedżerów, Warszawa.

Keashly, L., \& Jagatic, K. (2003). By any other name. In S. Einarsen, H. Hoel, D. Zapf, \& C. L. Cooper (Eds.). Bullying and emotional abuse in the workplace (pp. 31-61). Taylor \& Francis.

Kelloway, E. K., \& Day, A. L. (2005). La constitution d'un milieu de travail sain: ce que nous savons jusqu'à maintenant [Building a healthy workplace: What we know so far]. Revue Canadienne des Sciences du Comportement, 37, 236-249.doi.org/10.1037/ h0092529 (1)

Kenrick, D. T., Neuberg, S. L., \& Cialdini, R. B. (2006). Psychologia społeczna [Social psychology] (A. Nowak, O. Waśkiewicz, M. Trzebiatowska, \& M. Orski, Trans). Gdańskie Wydawnictwo Psychologiczne.

Kivimakï, M., Virtanen, M., Vartia, M., Elovaino, M., Vahtera, J., \& Keltikangas-Järvinen, L. (2003). Workplace bullying and the risk of cardiovascular disease and depression. Occupational and Environmental Medicine, 60, 779-783. doi: 10.1136/ oem.60.10.779 سلس

Kudielka, B. M., \& Kern, S. (2004). Cortisol day profiles in victims of mobbing (bullying at the workplace): Preliminary results of a first psychobiological field study. Journal of Psychosomatic Research, 56, 149-150. doi: 10.1016/S0022-3999(3)00126-0 
Lewandowska, J., \& Wenzel, M. (2004). Praca jako wartość [Work as a Value], komunikat z badań [research statement]. Centralny Instytut Badania Opinii Społecznej. Retrieved from https:// www.cbos.pl/SPISKOM.POL/2004/K_077_04.pdf

Leymann, H. (1996a). La persécution au travail [Bullying at work]. Editions du Seuil.

Leymann, H. (1996b). The content and development of mobbing at work. European Journal of Work and Organizational Psychology, 5, 165-184. doi: 10.1080/13594329608414853 سلسلسل| Leymann, H., \& Gustafsson, A. (1996). Mobbing at work and the development of post-traumatic stress disorders. European Journal of Work and Organizational Psychology, 5, 251-275. doi:

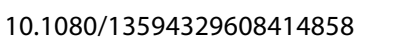

Łuszczyńska, A., \& Cieślak, R. (2005). Protective, promotive, and buffeting effects of perceived social support in managerial stress: The moderating role of personality. Anxiety, Stress, and Coping, 18, 227-244. doi: 10.1080/10615800500125587 سلسلسل|

Mahyew, C., McCarthy, P., Chappell, D., Quinlan, M., Barker, M., \& Sheehan, M. (2004). Measuring the extent of impact from occupational violence and bullying on traumatized workers. Employee Responsibilities and Rights Journal, 16, 117-134. doi: 10.1023/B:ERRJ.0000038648.08568.4 سلس

Makowska, Z., \& Merecz, D. (2001). Polska adaptacja Kwestionariuszy Ogólnego Stanu Zdrowia Davida Goldberga: GHQ-12 i GHQ-28 [Polish adaptation of David Goldberg's General Health Questionnaire: GHQ-12 and GHQ-28]. Instytut Medycyny Pracy im. prof. J. Nofera.

Matthiesen, S. B, \& Einarsen, S. (2004). Psychiatric distress and symptoms of PTSD among victims of bullying at work. British Journal of Guidance \& Counseling, 32, 335-356. doi: 10.1080/03069880410001723558 سلس الس

Mikkelsen, E. G., \& Einarsen, S. (2001). Bullying in Danish worklife: Prevalence and health correlates. European Journal of Work and Organizational Psychology, 10, 393-413. doi: 10.1080/13594320143000816 الس السلس

Mikkelsen, E. G., \& Einarsen, S. (2002a). Relationship between exposure to bullying at work and psychological and psychosomatic health complaints: The role of state negative affectivity and generalized self-efficacy. Scandinavian Journal of Psychology, 43, 397-405. doi: 10.1111/1467-9450.00307 السلسلسلس

Mikkelsen, E. G., \& Einarsen, S. (2002b). Basic assumptions and symptoms of post-traumatic stress among victims of bullying at work. European Journal of Work and Organizational Psychology, 11, 87-111. doi: 10.1080/13594320143000861 1ل. ل1

Narayanan, L., Menon, S., \& Spector, P. E. (1999). Stress in the workplace: A comparison of gender and occupations. Journal of Organizational Behavior, 20, 63-73. doi: 10.1002/(SICI)10991379(199901)20:1<63::AID-JOB873>3.0.CO;2-J

Niedl, K. (1996). Mobbing and well-being: Economic and personnel development Implications. European Journal of Work and Organizational Psychology, 5, 239-249. doi: 10.1080/13594329608414857 اليلمالس
Nielsen, M. B., \& Einarsen, S. (2012). Outcomes of exposure to workplace bullying: A meta-analytic review. Work \& Stress, 26, 309-332. doi: 10.1080/02678373.2012.734709 سلس ل1

Nielsen, M. B., \& Einarsen, S (2018). What we know, what we do not know, and what we should and could have known about workplace bullying: An overview of the literature and agenda for future research. Aggression and Violent Behavior, 42, 71-83. doi: 10.1016/j.avb.2018.06.007 الس السلسلة

Nielsen, M. B., Einarsen, S., Notelaers, G., \& Nielsen, G. H. (2016). Does exposure to bullying behaviors at the workplace contribute to later suicidal ideation? A three-wave longitudinal study. Scandinavian Journal of Work, Environment \& Health, 42, 246-250. doi: 10.5271/sjweh.3554 الس السلسل

Nielsen, M. B., Glasø, L, \& Einarsen, S. (2017). Exposure to workplace harassment and the Five Factor Model of personality: A meta-analysis. Personality and Individual Differences, 104, 195-206. doi: 10.1016/j.paid.2016.08.015 (1ل1)

Pavot, W., \& Diener, E. (2008). The Satisfaction with Life Scale and the emerging construct of life satisfaction. The Journal of Positive Psychology, 3, 137-152. doi: 10.1080/17439760701756946 المالسلسلة

Peregoy, J. J., \& Schliebner, C. T. (1990). Long-term unemployment: Effects and counselling interventions. International Journal for the Advancement of Counselling, 13, 193-204. doi: 10.1007/BF00118484 1لس

Plopa, M., Plopa, W., \& Skuzińska, A. (2017). Bullying at work, personality and subjective well-being. Journal of Occupational Health Psychology, 22, 19-27. http://dx.doi.org/10.1037/ a0040320 سلس

Pospiszyl, I. (2003). Ofiary chroniczne. Przypadek czy konieczność [Chronic victims. Coincidence or necessity]. Wydawnictwo Akademii Pedagogiki Specjalnej.

Quine, L. (2001). Workplace bullying in nurses. Journal of Health

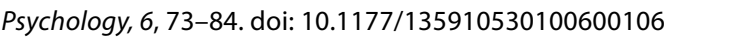

Rayner, C. (1997). The incidence of workplace bullying. Journal of Community and Applied Social Psychology, 7, 199-208. doi: 10.1002/(SICI)1099-1298(199706)7:3<199::AIDCASP418>3.0.CO;2-H Wلسلسلس

Rayner, C., Hoel, H., \& Cooper, C. L. (Eds.) (2002). Workplace bullying. What we know, who is to blame, and what can we do? Taylor \& Francis.

Robinson, S. L. \& Bennett, R. J. (1995). A typology of deviant workplace behaviors: A multidimensional scaling study. Academy of Management Journal, 38, 555-572. doi: 10.2307/256693 البلالسلسل

Rodriguez-Muñoz, A., Moreno-Jiménez, B., \& Sanz-Vergel, A. I. (2015). Reciprocal relations between workplace bullying, anxiety, and vigor: A two-wave longitudinal study. Anxiety, Stress, \&

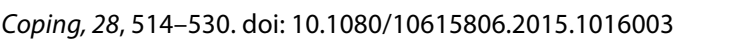
Salin, D. (2003). Ways of explaining workplace bullying: A review of enabling, motivating and precipitating structures and processes in the work environment. Human Relations, 56, 1213-1232. doi: 10.1177/00187267035610003 الس السلسل

Schat, A. C. H., \& Kelloway, E. K. (2003). Reducing the adverse con- 
sequences of workplace aggression and violence: The buffering effects of organizational support. Journal of Occupational Health Psychology, 8, 110-122. doi: 10.1037/1076-8998.8.2.110 الس السلسل

Soares, A. (2006). Les bleus à l'âme: le harcèlement psychologique chez les cols bleus de la ville de Montréal [Blueprints in the soul: psychological harassment among blue-collar workers in the city of Montreal] Université de Québec Retrieved from www.scfp301.qc.ca/document/rapport $\% 20$ cols $\% 20$ bleus $\% 20$ soares.pdf

Tamres, L. K., Janicki, D., \& Helgeson, V. S. (2002). Sex differences in coping behavior: A meta-analytic review and an examination of relative coping. Personality and Social Psychology Review, 6, 2-30. doi: 10.1207/S15327957PSPR0601_1 1 الس

Tepper, B. J. (2000). Consequences of abusive supervision. Academy of Management Journal, 43, 178-190. doi:

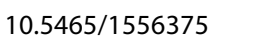

Vartia, M. (2001). Consequences of workplace bullying with respect to the well-being of its targets and the observers of bullying. Scandinavian Journal of Work Environment and Health, 27, 63-69. doi: 10.5271/sjweh.588 المالسلسلس
Vartia-Vaananen, M. (2003). Workplace bullying - a study on the work environment, well-being and health. [Doctoral thesis, University of Helsinki]. Retrieved from https:// helda.helsinki.fi/bitstream/handle/10138/19884/workplac. pdf?sequence=3\&isAllowed $=y$

Warszewska-Makuch, M. (2007). Polska adaptacja kwestionariusza NAQ do pomiaru mobbingu. [Polish Adaptation of the NAQ Questionnaire for Measuring Bullying] Bezpieczeństwo

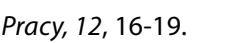

Warszewska-Makuch, M. (2008). Zjawisko mobbingu wśród nauczy-

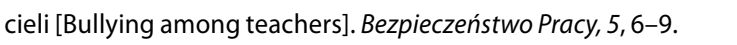
Whisman, M. A., \& McClelland, G. H. (2005). Designing, testing, and interpreting interactions and moderator effects in family research. Journal of Family Psychology, 19, 111-120. doi:

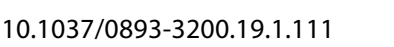

Zapf, D., Knorz, C., \& Kulla, M. (1996). On the relationship between mobbing factors, and job content, social work environment, and health outcomes. European Journal of Work and Organizational Psychology, 5, 2, 215-237. doi: 10.1080/13594329608414856 الس السلس 